\title{
LABORATORY EVALUATION OF THREE BIOAGENT AGAINST THE EGYPTIAN SUBTERRANEAN TERMITE PSAMMOTERMES HYPOSTOMA (DESN.)
}

\author{
EL-DOSSOKI, S. A. ${ }^{1}$, S. M. EL-AWADY ${ }^{1}$, Y. EL-SEBAY ${ }^{2}$ AND \\ A.R. EL-BASSIOUNY ${ }^{2}$ \\ 1 - Dept. of Plant Protection, Fac. of Agric., Al-Azhar University, Cairo \\ 2 - Plant Protection Research Institute, ARC, Dokki, Giza
}

(Manuscript received 4 May 2008)

\begin{abstract}
Present work was conducted for studying biological control of the termite psammotermes hypostoma (sand termite) This study includes the following results: Toxicity results of Bacillus thuringiensis var. kurstaki against the termite psammotermes hypostoma revealed higher mortality values at the highest concentrations used $6 \mathrm{gm} / \mathrm{L}$, while the lowest concentrations gave moderate mortality values $53 \%$. Use of Beauveria bassiana, indicated negligible mortality values ranged between from (3.6$16.2 \%)$ at the three tested concentration. Application of nematodes (Steinernema carpocapsae) against subterranean termites, mortality has begun 24 hours post-treatment. The first concentration represented $(40.2 \%)$ mortality, the second concentration represented $(78.2 \%)$, and the highest used concentration gave complete mortality values $(100 \%)$. The $\mathrm{LT}_{50}$ for Dipel $2 X$ was 2.6, 3.01 and 4.9 days and 2.2, 3.2 and 7.3 days for Bacillus thuringiensis approximately.
\end{abstract}

\section{INTRODUCTION}

Termites represent one of the most important insects related to food kinds. Termites feed mainly on anything containing cellulose, wood, papers, clothes, trees, woody tissues of plants buildings constructional timbers causing big problems to houses and estimated the highly loss due to sand termite, psammotermes hypostoma and harvester termite, Anacanthotermes ochraceus (Burm.) attacks in Egypt. Due to the hidden life behavior of termite, is very difficult ecological studies. (Morsy et al., 1982). Sand termite, Psammotermes hypostoma (Desn.), one of subterranean termite, is very adaptable species and have a wide distribution in Egypt and the world causing several damages to any products or crops contain any source cellulose. Sand termites, $P$. hypostoma is restricted to areas where there is a proportion of clay of alluvium in the soils. It is considered to have a great economic importance in Egypt. This termite is widely dispersed all over the two sides of the River Nile and all oases in both Eastern and Western deserts.

Biological control is one of control methods used for environment protection. Several researches are conducted on the termite in Egypt and the world eg...El-Sebay 
and El-Bishry (1994), used the entomopathogenic nematodes, steinernema carpocapsae and S. glaseri against subterranean termites Anacanthotermes ochraceus, and gave good results. The entomopathogenic, bactericide, nematodes and fungicide were discussed by Ibay (1996), Epsky and Capinera (1988) and Delate et al. (1995).

The present work application of an attempt for biological control under laboratory condition including the following agents, bactericide (Bacillus thuringiensis), fungicide (Beauveria bassiana) and entomopathogenic nematodes (Steinernema carpocapsae). The study has been carried out throughout 1995 - 1996 at the termite laboratory, Plant Protection Research Institute (PPRI), Ministry of Agriculture, Dokki, Giza, Egypt. Throughout of importance in this study of the termite in Egypt, we using for all attempts and we hope to found a method of being able to control psammotermes hypostoma.

\section{MATERIALS AND METHODS}

\section{Insect collection:}

Subterranean termites, Psammotermes hypostoma (Desn.) were collected from Agric., Res., Station, Ezz El-Deen region at Ismailia Governorate. El-Sebay traps (El-Sebay modified trap, 1991) are used for termite collection Fig (1). Termites were separated from the traps and kept in petri-dishes provided with pieces of moistened card boards as a diet and moisture source for seven days. Healthy individuals of workers, 3-5 nymphal instars soldiers and alates, were used for the treatments.

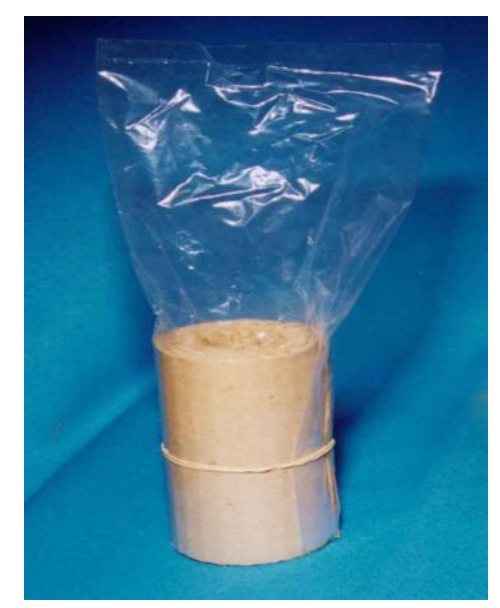

Fig (1): El-Sebay modified trap

\section{Treatments}

1. Bacterial formulation: Bacillus thuringiensis (B. t.) formulation:

Dipel 2X (Bacillus thuringiensis var. kurstaki) $32000 \mathrm{IU} / \mathrm{mg}$ as commercial formulation was used for preparation three concentrations of B.t. as follow: 
$2 \mathrm{gm} / \mathrm{L}$ distilled water $=6.4 \times 10^{6} \mathrm{IU} / \mathrm{L}$

$4 \mathrm{gm} / \mathrm{L}$ distilled water $=12.8 \times 10^{6} \mathrm{IU} / \mathrm{L}$

$6 \mathrm{gm} / \mathrm{L}$ distilled water $=19.2 \times 10^{6} \mathrm{IU} / \mathrm{L}$

2. Fungal formulation: Biofly (Beauveria bassiana), $3 \times 10^{7}$ cells $/ \mathrm{ml}$, as commercial formulation was used preparing in the following concentrations:

$2 \mathrm{ml} / \mathrm{L}$ distilled water $=6 \times 10^{7}$ cells $/ \mathrm{L}$

$4 \mathrm{ml} / \mathrm{L}$ distilled water $=12 \times 10^{7}$ cells $/ \mathrm{L}$

$6 \mathrm{ml} / \mathrm{L}$ distilled water $=18 \times 10^{7}$ cells $/ \mathrm{L}$

The cardboards used $(4 \times 5 \mathrm{~cm})$ were soaked for $5 \mathrm{~min}$. in the different concentrations for B.t. and fungal concentrations. Treated cardboards were placed in a petri-dishes which contain 100 termites of uniform individuals. A piece of agar was added as a moisture source. Control contained a cardboard soaked in a distilled water and agar media. All treatments were kept under a constant temperature of $27+1 \mathrm{C}^{\circ}$ in an incubator. Mortality data was recorded every 24 hours for 7 days.

3. Nematode formulation: Steinernema carpocapsae (Berliner) was provided as a pure culture by Department of Pest Physiology, Plant Protection Research Institute. A stock solution of $1000 \mathrm{IJs} / \mathrm{ml}$ was prepared as numbers of IJs (Insect Juveniles). A micropipette $(1 \mathrm{ml})$ was used to prepare different concentrations. Three concentrations were prepared as follow:

1.. IJs/rep. $=1 \mathrm{IJs} /$ insect.

r.. IJs/rep. $=2 \mathrm{IJs} /$ insect.

$\varepsilon$.. IJs/rep. $=4 \mathrm{IJs} /$ insect.

IJs = Insect Juveniles

For each treatment, 5 replicates were used (100 termites/petri-dish). Each treatment contained 100 healthy termites placed in a sterilized petri- dish. A concentration of the suspension was added to a piece of agar placed beside cardboard. All treatments were kept under a constant temperature of $27+1 \mathrm{C}^{\circ}$ in an incubator. Daily data were recorded by counting the number of dead termites until 7 days. Dead individuals of each treatment were kept separately in sterilized petri-dish provided by agar media and examined every day to detect nematode development. Control contained a wet card-board pieces $(4 \times 4 \mathrm{~cm})$ to provide the food for the termites and moisture.

Mortality was corrected according Abbott's formula (Abbott, 1925). $\mathrm{LT}_{50}$ values were calculated according to Finney (1971). Lethal time $\left(L_{50}\right)$ were calculated by using a computer program of Proban. 


\section{RESULTS AND DISCUSSION}

\section{Efficiency of $B$. thuringiensis formulation:}

Data in Tables (1 and 2) showed the effect of the three treatments of Bacillus thuringiensis against termite $P$. hypostoma. Data in all treatments appear the mortality occurred in the third day post-treatment nearly in all concentrations. In the first concentration $2 \mathrm{gm} / \mathrm{L}$ the mortality increased through the third to fourth day only, represented (45\%) to reach (53\%) mortality in the fourth day, while in the second and third treatment $4 \mathrm{gm}$ and $6 \mathrm{gm} / \mathrm{L}$, respectively, mortality showed gradual death with percentage of $(60-100 \%)$ for the second treatment, and $(76-100 \%)$ for the third treatment, but the kill of the high concentration $6 \mathrm{gm} / \mathrm{L}$ showed rapid death than the former. According to Fig. (2) the $\mathrm{LT}_{50}$ for all was $(4.95,3.01$ and 2.67 days) for the first, second and third treatments, respectively. In comparison with the control, the average natural mortality percentages were $(1 \%)$. Termite when fed on the bait, larvae appear quicker and higher mortality followed by workers. Soldiers were more tolerance. The infested termites suffered and showed slow movement except soldiers. The hind-gut was converted to the brown colour, then showed burst before death.

These results are in agreement with those of Ibay (1996), who mentioned that the nymphs gave a higher mean toxicity when fed on the diet treated with B.t. of subterranean termites. Isik and Yamilmaz (1992) reported that $B$. $t$. gave results relatively effective in the control of termites. Data agree with El-Sebay and El-Bishry (1994), who resulted that the lowest mortality rate of Anacanthotermes ochraceus was obtained in case of B.t. treatment.

Table 1. Number of dead psammotermes hypostoma individuals resulted from Dipel $2 X$, (B.t.) treatment at $27 \pm 1 C^{\circ}$.

\begin{tabular}{|c|c|c|c|c|c|c|c|c|}
\hline \multirow[t]{2}{*}{ Conc. } & \multirow[t]{2}{*}{ Replicates } & \multicolumn{7}{|c|}{ Number of dead individuals at indicated periods (days) } \\
\hline & & 1 & $r$ & $r$ & $\varepsilon$ & 。 & 7 & $v$ \\
\hline \multirow{5}{*}{$\mathrm{rgm} / \mathrm{L}$} & 1 & . & . & or & 7. & 7. & 7. & 7. \\
\hline & 2 & . & . & rی & rt & it & Tr & Tr \\
\hline & 3 & . & · & $\leqslant 9$ & or & or & or & or \\
\hline & 4 & $\cdot$ & $\cdot$ & $\varepsilon$. & $\varepsilon r$ & $\varepsilon r$ & $\varepsilon r$ & $\leqslant r$ \\
\hline & 5 & . & . & $\varepsilon r$ & $\varepsilon v$ & $\varepsilon v$ & $\varepsilon \vee$ & $\varepsilon v$ \\
\hline \multirow{5}{*}{$\leqslant g m / L$} & 1 & . & . & 79 & 10 & qr & $1 \cdots$ & $1 \ldots$ \\
\hline & 2 & . & . & 01 & 11 & $9 V$ & $1 \ldots$ & $1 \ldots$ \\
\hline & 3 & . & . & TV & TV & 10 & $1 \ldots$ & $1 \ldots$ \\
\hline & 4 & . & $\cdot$ & 11 & VA & 94 & $1 \ldots$ & $1 \ldots$ \\
\hline & 5 & . & . & VY & $\wedge$ & 90 & $1 \ldots$ & $1 \ldots$ \\
\hline \multirow{5}{*}{$\mathrm{rgm} / \mathrm{L}$} & 1 & . & . & ov & AV & $1 \ldots$ & $1 \ldots$ & $1 \ldots$ \\
\hline & 2 & . & . & 11 & 94 & $1 \ldots$ & $1 \ldots$ & $1 \ldots$ \\
\hline & 3 & . & $\cdot$ & TV & 9V & $1 \ldots$ & $1 \cdots$ & $1 \ldots$ \\
\hline & 4 & . & . & 10 & 91 & $1 \ldots$ & $1 \ldots$ & $1 \ldots$ \\
\hline & 5 & . & . & NV & Tा & $1 \ldots$ & $1 \ldots$ & $1 \ldots$ \\
\hline
\end{tabular}


Control

\begin{tabular}{|c|c|}
\hline & $r$ \\
\hline
\end{tabular}

r

r

Table 2. \% Mortality of psammotermes hypostoma individuals resulted from Dipel $2 \mathrm{X}$, (B.t.) treatment at $27 \pm 1 \mathrm{C}^{\circ}$.

\begin{tabular}{|c|c|c|c|c|c|c|c|}
\hline \multirow[t]{2}{*}{ Conc. } & \multicolumn{7}{|c|}{$\%$ Mortality at indicated periods (days) } \\
\hline & 1 & r & r & $\varepsilon$ & $\circ$ & 1 & v \\
\hline $\mathrm{rgm} / \mathrm{L}$ & . & 0 & $\varepsilon 0 . \varepsilon$ & or.. & or.. & or.. & or.. \\
\hline$\varepsilon g m / L$ & $\cdot$ & 0 & $7 . .1$ & v৭.^ & 9r.\& & 99.7 & $1 \ldots$ \\
\hline $\mathrm{rgm} / \mathrm{L}$ & · & 0 & $\vee \Upsilon . \wedge$ & 94.7 & $1 \ldots$ & $1 \ldots$ & $1 \ldots$ \\
\hline Control & $\cdot$ & $\cdot$ & 1.7 & 1.7 & 1.7 & 1.7 & 1.7 \\
\hline
\end{tabular}

$2 \mathrm{gm} / \mathrm{L}=6.4 \times 10^{6} \mathrm{IU} / \mathrm{L}$

$4 \mathrm{gm} / \mathrm{L}=12.8 \times 10^{6} \mathrm{IU} / \mathrm{L}$

$6 \mathrm{gm} / \mathrm{L}=19.2 \times 10^{6} \mathrm{IU} / \mathrm{L}$

\section{Efficiency of $B$. bassiana formulation:}

According to Tables ( 3 and 4 ) data showed the effect of the three doses of $B$. bassiana against subterranean termites, $P$. hypostoma. Data in all treatments revealed that mortality started post 48 hours nearly in all cases. Mortality percentages in the first treatment $(2 \mathrm{ml} / \mathrm{L})$ was $3.6 \%$ in the third day, fixed through the tested day (7day), as well as the same trend in the second treatment $(4 \mathrm{ml} / \mathrm{L})$, whereas it was 10.6 in the course of seven days. While in the high dose $(6 \mathrm{ml} / \mathrm{L})$, termites showed slight mortality ranged from (12-16\%) in the third, fourth and fifth day to reach $(16.2 \%)$ in the sixth and seventh day. In comparison with the control, the average of mortality was $(0.2 \%)$. It was obvious that, lowest mortalities rates was obtained in the case of $B$. bassiana treatments. There were no evidence of mortality.

The obtained results are in agreement with those of Delate et al. (1995), who mentioned that the $B$. bassiana tested against Coptotermes formosonus. The results showed that the B. bassiana caused slower termite mortality. Jones et al. (1996) reported that the $B$. bassiana as a control against $C$. formosonus. The results showed that the Metarrhizium anisopliae strain were more virulent than the B. bassiana strains. Contrarly, data are in disagreement with Khan et al. (1993) who reported that the $B$. bassiana was the most effective pathogen against termites. Wells et al. (1995) mentioned that the $B$. bassiana isolated from Orthoptera, Lepodoptera, Homoptera, Dermaptera and Isooptera against $C$. formosonus was virulent to the termites.

Efficiency of entomopathogenic nematodes formulatin, S. carpocapsae:

Data in Tables (5 and 6) showed the efficacy of nematodes, Steinernema carpocapasae against subterranean termite, P. hypostomae. Data revealed that at all used concentrations, the tested nematodes gave higher mortality than $B$. thuringiensi 
and $B$. bassiana. The first concentration $(0.1 \mathrm{ml}=100 \mathrm{IJs} /$ replicate $=1 \mathrm{IJs} /$ insect $)$, mortality began from the second day, presented (2.4\%) and increased gradually to be stable from the fifth day to seventh day, represented $(40.2 \%)$. While the mortality was $(28.4 \%)$ and increased to reach maximum in the sixth day, represented (78.2\%) from the total number of tested individuals in the second treatment $(0.2 \mathrm{ml}=200$ IJs/replicate $=2 \mathrm{IJs} /$ insect). The highly mortalities percentages were obtained when termites treated with the third dose $(0.4 \mathrm{ml}=400 \mathrm{IJs} /$ replicate $=4 \mathrm{IJs} /$ insect $)$, whereas the mortality percentage was (31.4\%) in the second day and reached its maximum (100\%) in the sixth day. In Fig. (4) The calculated $L T_{50}$ was $(7.32,3.21$ and 2.23 days) for the three treatments, respectively. The symptoms of death of the contaminated termites were sluggish, the body tissues were ragged, the juveniles emerged from the body cavity of dead individuals after about 5-7 days nearly. Juveniles emerged from soft body regions, specially prothorax, lateral abdominal regions, anus and the head pits. The termites workers were more susceptible to nematodes than alates and soldiers.

Table 3. Number of dead psammotermes hypostoma individuals resulted from Buveria bassiana treatment at $27 \pm 1 \mathrm{C}^{\circ}$.

\begin{tabular}{|c|c|c|c|c|c|c|c|c|}
\hline \multirow[t]{2}{*}{ Conc. } & \multirow[t]{2}{*}{ Replicates } & \multicolumn{7}{|c|}{ Number of dead individuals at indicated periods (days) } \\
\hline & & 1 & r & $r$ & $\varepsilon$ & 0 & 7 & v \\
\hline \multirow{5}{*}{$\mathrm{rml} / \mathrm{L}$} & 1 & . & . & 。 & $\circ$ & 。 & 。 & ○ \\
\hline & 2 & · & · & $\circ$ & $\circ$ & $\circ$ & $\circ$ & $\circ$ \\
\hline & 3 & · & · & 1 & 1 & 7 & 7 & 7 \\
\hline & 4 & · & · & . & . & $\cdot$ & . & . \\
\hline & 5 & · & · & r & r & r & r & r \\
\hline \multirow{5}{*}{$\varepsilon \mathrm{ml} / \mathrm{L}$} & 1 & · & · & 1 & 1 & 1 & 1 & 1 \\
\hline & 2 & . & . & ir & ir & IT & ir & IT \\
\hline & 3 & . & . & v & $v$ & v & V & v \\
\hline & 4 & . & . & r & r & Tr & r & r \\
\hline & 5 & . & . & 1. & 1. & 1. & 1. & 1. \\
\hline \multirow{5}{*}{$7 \mathrm{ml} / \mathrm{L}$} & 1 & . & . & $\wedge$ & 1. & 1. & 1. & 1. \\
\hline & 2 & . & . & $1 \varepsilon$ & iv & IV & iv & IV \\
\hline & 3 & . & . & 17 & r4 & Y & T & ד \\
\hline & 4 & . & . & 14 & 10 & 10 & 10 & 10 \\
\hline & 5 & . & . & 11 & ir & Kr & ir & ir \\
\hline \multicolumn{2}{|c|}{ Control } & . & . & 1 & 1 & 1 & 1 & 1 \\
\hline
\end{tabular}


Table 4. \% Mortality of psammotermes hypostoma individuals resulted from Buveria bassiana treatment at $27 \pm 1 C^{\circ}$.

\begin{tabular}{|c|c|c|c|c|c|c|c|}
\hline \multirow[t]{2}{*}{ Conc. } & \multicolumn{7}{|c|}{ \%Mortality at indicated periods (days) } \\
\hline & 1 & r & r & $\varepsilon$ & o & 7 & V \\
\hline $\mathrm{rml} / \mathrm{L}$ & 0 & 0 & r. & $r .7$ & r.7 & r.૫ & r.7 \\
\hline$\varepsilon \mathrm{ml} / \mathrm{L}$ & 0 & 0 & $1 \cdot .7$ & $1 \cdot .7$ & $1 . .7$ & $1 . .7$ & $1 \cdot .7$ \\
\hline $\mathrm{Tml} / \mathrm{L}$ & 0 & 0 & Ir. & 17. & 17. & 17.4 & 17.4 \\
\hline Control & . & . &.$r$ &.$r$ &.$r$ &.$r$ &.$r$ \\
\hline
\end{tabular}

$\mathrm{rml} / \mathrm{L}=6 \times 10^{7}$ cells $/ \mathrm{L}$

$\leq \mathrm{ml} / \mathrm{L}=12 \times 10^{7}$ cells/L

זml/ L = $18 \times 10^{7}$ cells/L

The previous data are regularly with Epsky and Capinera (1988), who found that Reticulitermes tibalis, workers were susceptible to nematodes $S$. carpocapsae. While the results disagree with those of Mauldin and Beal (1989). The authors tested the efficacy of $S$. feltia against Reticulitermes spp. and Heterorhabditis heliothidis in laboratory, the termites survival rates in the nematode treatment and in the untreated control did not differ significantly. Also, the data are in agreement with the results of Amarasingh and Homonick (1993a\&b), they mentioned that the $S$. carpocapsae were better controlling against Posteletrotemes militaris than other isolates tested. El-Sebay and El-Bishry (1994) found that $S$. carpocapsae was the most effective bioagent followed by $S$. glaseri against subterranean termites Anacanthotermes ochraceus. But the results are different with the same author when they found that the nematodes development inside dead termites was detected only in case of $S$. gloseri, while the $S$. carpocapsae failed to complete its life cycle.

Table 5. Number of dead psammotermes hypostoma individuals resulted from Steinernema carpocapsae treatment at $27 \pm 1 \mathrm{C}^{\circ}$.

\begin{tabular}{|c|c|c|c|c|c|c|c|c|}
\hline \multirow{2}{*}{$\begin{array}{l}\text { Conc. } \\
\text { IJs/ml }\end{array}$} & \multirow[t]{2}{*}{ Replicates } & \multicolumn{7}{|c|}{ Number of dead individuals at indicated periods (days) } \\
\hline & & 1 & r & r & $\varepsilon$ & 0 & 7 & $\mathrm{v}$ \\
\hline \multirow{5}{*}{.. $\mathrm{ml}$} & 1 & . & 1 & r) & rA & rV & re & rV \\
\hline & 2 & . & $\varepsilon$ & 11 & $r$ & $\varepsilon r$ & $\varepsilon r$ & $\varepsilon r$ \\
\hline & 3 & . & r & r. & $r$. & 纟o & «o & $\leq 0$ \\
\hline & 4 & · & $r$ & iv & rt & rq & rq & rq \\
\hline & 5 & . & r & 17 & $r V$ & $r \Lambda$ & $r \Lambda$ & rᄉ \\
\hline \multirow{5}{*}{$\because$ rml } & 1 & . & $r q$ & 0. & 4 & Vr & VY & $V r$ \\
\hline & 2 & . & $r$. & or & 70 & $\mathrm{VA}$ & Nr & Ar \\
\hline & 3 & . & rI & $\leq 9$ & Tr & Vq & $\wedge 1$ & N1 \\
\hline & 4 & . & $r \Lambda$ & $\leqslant \varepsilon$ & $v$. & $V \varepsilon$ & $\mathrm{VI}$ & $V T$ \\
\hline & 5 & . & $r \varepsilon$ & $\leqslant 7$ & TV & A. & ^. & $\wedge$. \\
\hline \multirow{5}{*}{$\therefore \leq \mathrm{ml}$} & 1 & . & r. & זr & $\mathrm{Vq}$ & $9 \leqslant$ & $1 \ldots$ & $1 \ldots$ \\
\hline & 2 & . & rA & TY & ה & 94 & $1 \ldots$ & $1 \ldots$ \\
\hline & 3 & . & זr & 70 & 91 & $1 \ldots$ & $1 \ldots$ & $1 \ldots$ \\
\hline & 4 & . & $r q$ & VY & 90 & $1 \ldots$ & $1 \ldots$ & $1 \ldots$ \\
\hline & 5 & . & rV & 79 & 91 & $1 \ldots$ & $1 \ldots$ & $1 \ldots$ \\
\hline
\end{tabular}




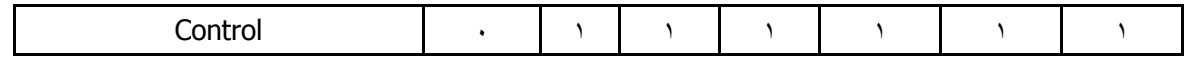

Table 6. \% Mortality of psammotermes hypostoma individuals resulted from steinernema carpocapsae treatment at $27 \pm 1 \mathrm{C}^{\circ}$.

\begin{tabular}{|c|c|c|c|c|c|c|c|}
\hline \multirow{2}{*}{$\begin{array}{l}\text { Conc. } \\
\text { IJs/ml }\end{array}$} & \multicolumn{7}{|c|}{$\%$ Mortality at indicated periods (days) } \\
\hline & 1 & r & $r$ & $\Sigma$ & 0 & 7 & V \\
\hline$\cdot .1 \mathrm{ml}$ & 0 & $\Gamma . \Sigma$ & $1 \Lambda . \Sigma$ & TV.T & $\Sigma \cdot . \Gamma$ & $\varepsilon \cdot . \Gamma$ & $\Sigma \cdot . \Gamma$ \\
\hline •.rml & 0 & $\Gamma \wedge . \Sigma$ & $\sum \Lambda . T$ & $70 . \Sigma$ & V7. .7 & V^.T & VA.T \\
\hline$\cdot . \Sigma \mathrm{ml}$ & 0 & rI.乏 & $7 \Sigma . \Gamma$ & $\Lambda V . \wedge$ & 9V.乏 & $1 \cdots$ & $1 \cdots$ \\
\hline Control & - & $1 . r$ & $1 . r$ & $1 . r$ & $1 . r$ & $1 . r$ & $1 . r$ \\
\hline
\end{tabular}

$. . \mathrm{ml}=100 \mathrm{IJs}=1 \mathrm{IJs} /$ insect

$. r \mathrm{ml}=200 \mathrm{IJs}=2 \mathrm{IJs} /$ insect

$$
. . \varepsilon \mathrm{ml}=400 \mathrm{IJs}=4 \mathrm{IJs} / \text { insect }
$$

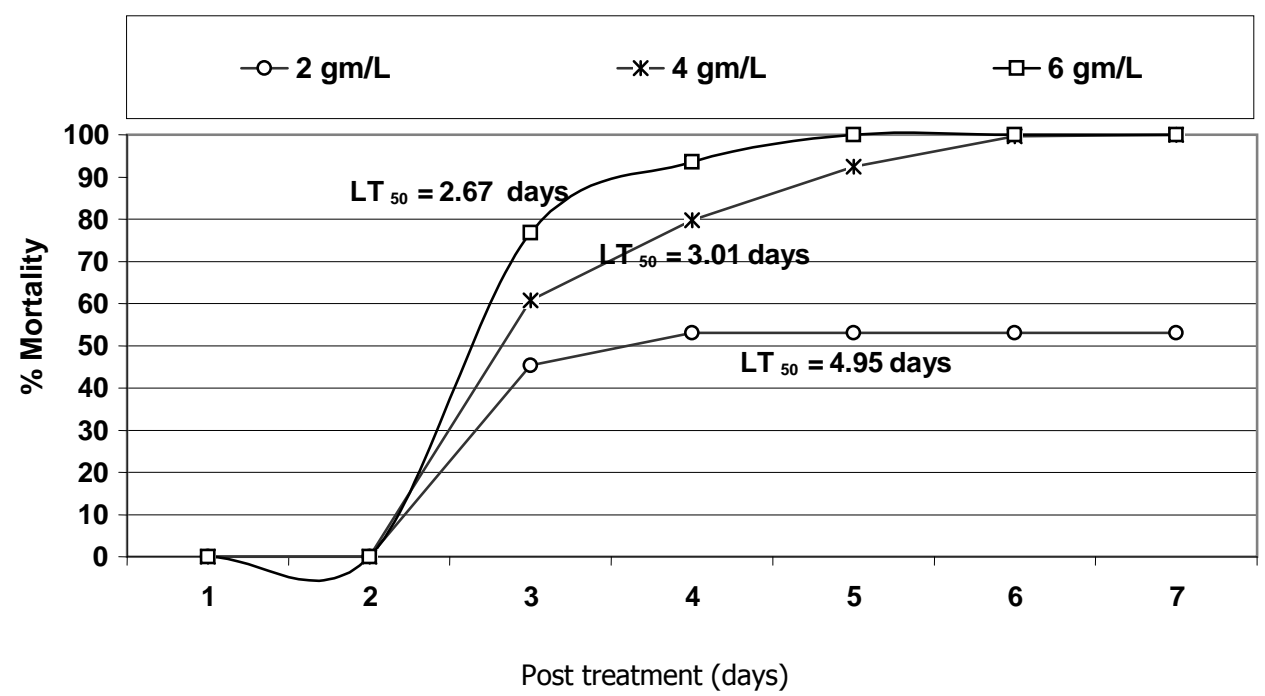

Fig. 2. Laboratory evaluation of Dipel $X(2,4$ and $6 \mathrm{gm} / \mathrm{L})$ agains the termite psammotermes hypostoma 


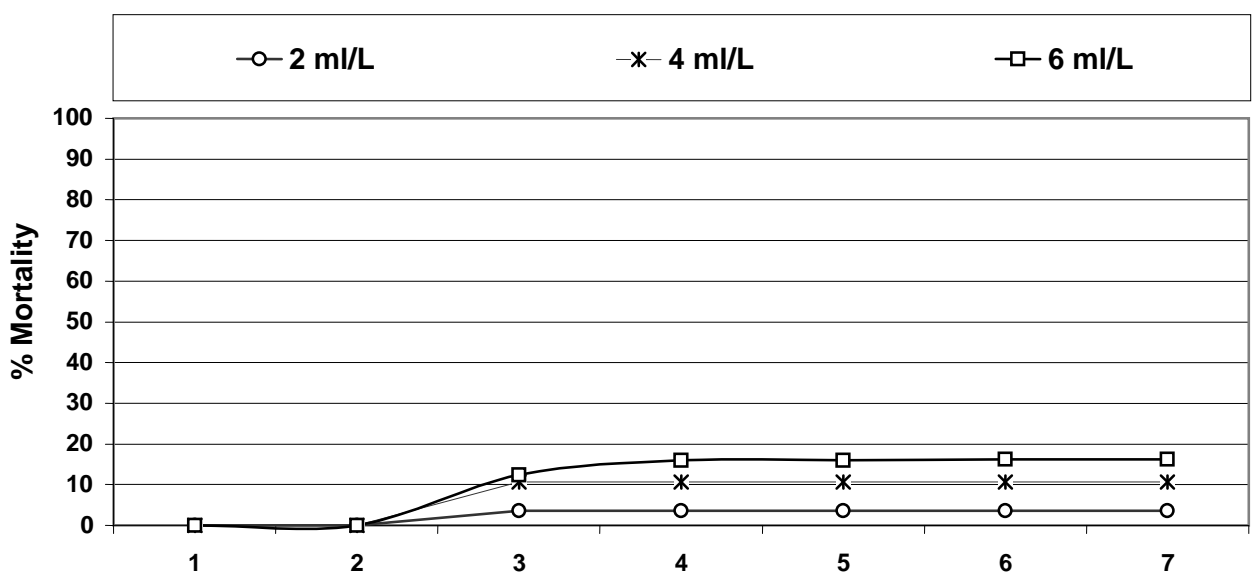

Post treatment (days)

Fig. 3. Laboratory evaluation of Beauverla bassiana $(2,4$ and $6 \mathrm{ml} / \mathrm{L})$ against the termite Psammotermes hypostoma

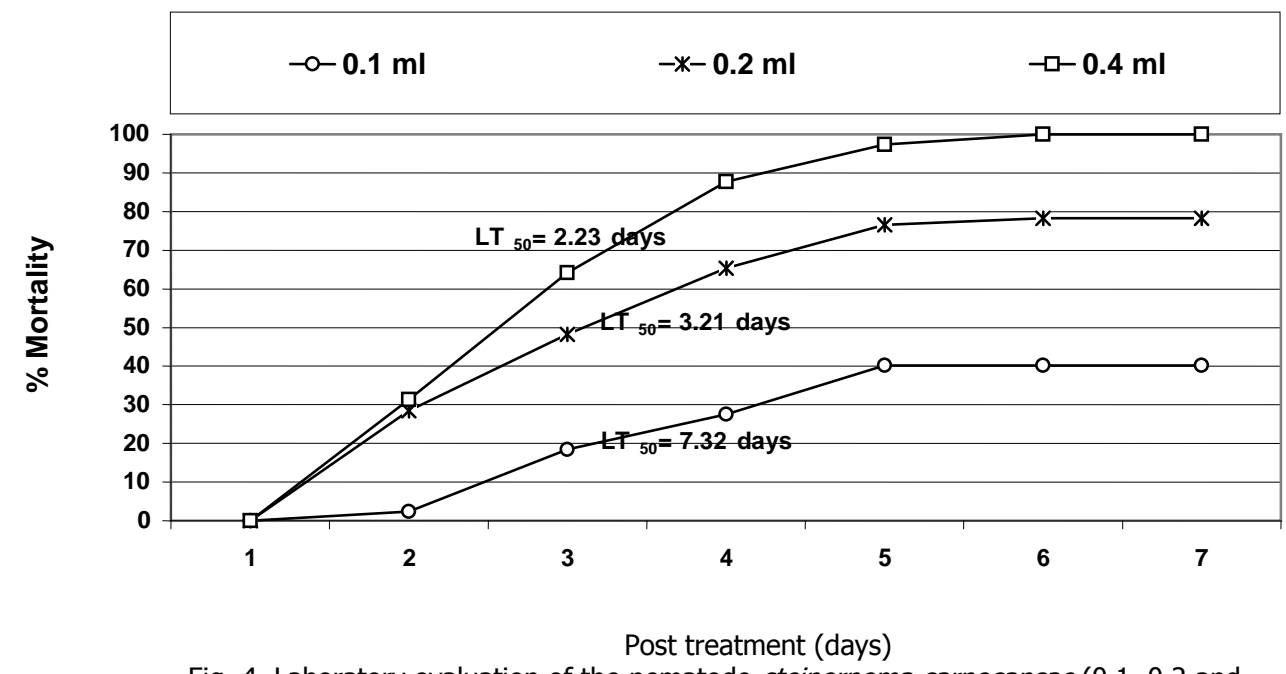

Fig. 4. Laboratory evaluation of the nematode steinernema carpocapsae $(0.1,0.2$ and $0.4 \mathrm{ml}$ ) against the termite psammotermes hypostoma

\section{REFERENCES}

1. Abbott, W. S. 1925. A method of computing the effectiveness of an insecticides. J. Econ. Entomol., 18: 265-267.

2. Amarasingh, L. D. and W. M. Homonick. 1993a. Efficacy of entomopathogenic nematodes to control up-country live wood termite. Sri-Lanka J. Tea Sci., 62 (1): 16-24.

3. Amarasingh, L. D. and W. M. Homonick. 1993b. Potenianl of using entomopathogenic nematodes to control up-country live wood termite (Postelectrotermes militaris). Sri-Lanka J. Tea Sci., 62 (1): 66-78.

4. Delate, K. M., J. K. Grace and Ch. M. Torne. 1995. Potential use of pathogenic fungi in baits to control the Formosan subterranean termite (Isoptera : Rhinotemitidae). J. Appl. Ent., 119 (6): 429-433. 
5. El-Sebay, Y. 1991. A modified trap for El-Sebay subterranean termies. Fourth Arab Cong. of Plant Protection, Cairo, 1-5 Dec. 1991.

6. El-Sebay, Y. and M. H. El-Bishry. 1994. Laboratory evaluation of two biocontrol agents against termite Anaconthotermes ochraceus (Burm.). Egyptian J. Biol. Pest Control, 4 (2): 95-100.

7. Epsky, N. D. and J. L. Capinera. 1988. Efficacy of entomogenous nematodes Steinernema feltiae against a subterranean termite Reticulitermes tibialis (Isoptera : Rhinotermitidae). J. Econ. Entomol., 81 (5): 1313-1317.

8. Finney, D. J. 1971. Probit analysis. A Statistical Treatment of the Sigmoid Response Curve. 7th Ed., Cambridge Univ. Press, England.

9. Ibay, L. A. 1996. Laboratory toxicity of two strains of Bacillus thuringiensis (Berliner) against subterranean termite. Sci. J. Philippines, 5 (2), 6 (1).

10. Isik, M. and A. F. Yamilmaz. 1992. Studies on the natural enemies and control measures of the fall webworm (Hyphantria cunea Drury, Lep. : Arcitidae) in hazelnut plantation in samsum. Ziria Mucadele Arastirma Yiigi, No. 22-23, 55-58.

11. Jones, W. E., J. K. Grace and M. Tamashiro. 1996. Virulence of seven iolates of Beauveria bassiana and Metrahizium anisopliae to Captotremes formosonus (Isoptera: Rhinotermitidae). Environ. Entomol., 25 (2): 481-487.

12. Khan, H. K., S. Jayarage and M. Gopalan. 1993. Muscardine fiungi for the biological control of agroforestry termite, Odonotermes obesus (Rambur). Insect Sci. and Appl., 14 (4): 529-535.

13. Mauldin, J. K. and R. H. Beal. 1989. Entomogenous nematodes for control of subterranean termites, Reticulitermes spp. (Isoptera : Rhinotermitidae). J. Econ. Entomol., 82 (6): 1638-1642.

14. Morsy, M. M., M. M. Rizk and F. M. Khalil. 1982. Effect of thermo rhythm on termite food consumption. Assiut J. Agric. Sci., 13 (3): 43-50.

15. Wells, J. D., J. R. Fuxa and G. Henderson. 1995. Virolence of four fungal pathogens to Captotermes formosonus (Isoptera: Rhinotermitidae). J. Ent. Sci., 30 (2): 208-215. 
تقييم معملى لثلاث مواد حيوية ضد النمل الأبيض التحت أرضى فى مصر

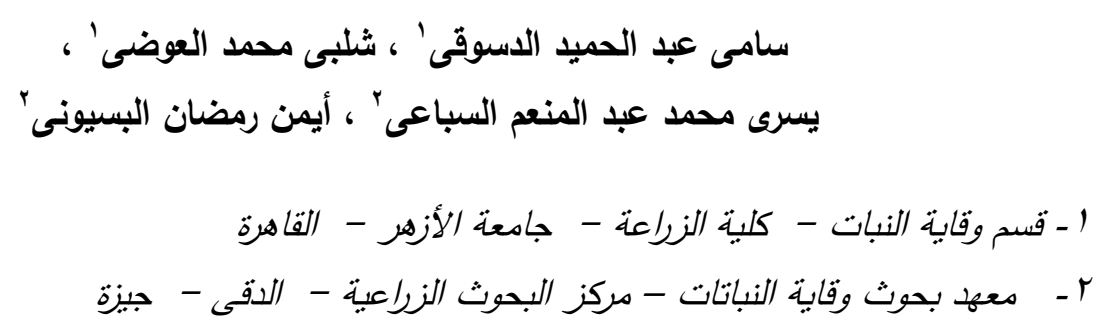

كان لاستخدام بكتريا الـ Bacillus thuringiensis (B.T) في مكافحة النمل الأبيض التحت أرضى

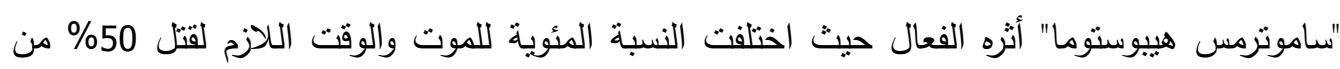
الحشرات المختبرة LT 50 باختلاف التركيز وتراوحت نسبة الموت ما بين 53 - 100 \% للتركيز الأدنى

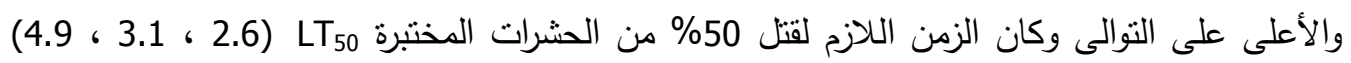

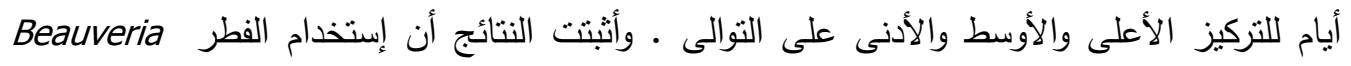
bassiana

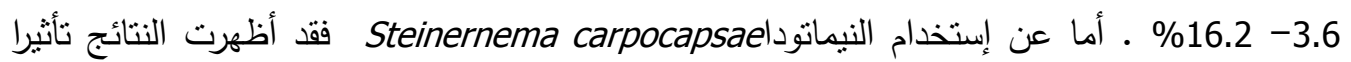
فعالا فى مكافحة النمل الأبيض التحت أرضى حيث بدأ عد نسبة الموت من اليوم الثاني للمعاملة وأعطى أقل تركيز نسبة موت مقدارها 40.2\% أما التركيز المتوسط أعطي نسبة موت مقدارها

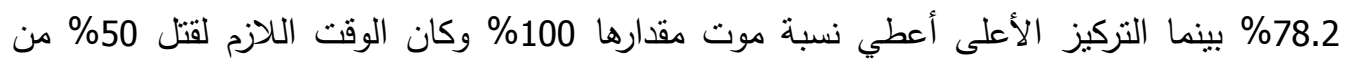

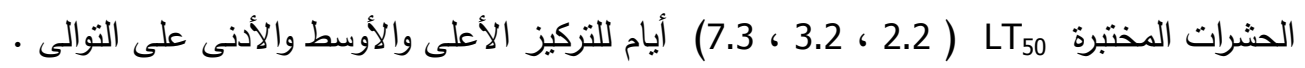

